\title{
Effect of Supplementation of Garlic (Allium sativum) and Nilavembu (Andrographis paniculata) on Hematological and Serum Biochemical Parameters of Commercial Broiler Chicken
}

\author{
Toriyali Arify ${ }^{1}$, S. Ezhil Valavan ${ }^{2 *}$, K. Manimaran ${ }^{3}$, A. Sundaresan ${ }^{4}$ and A. Varun ${ }^{1}$ \\ ${ }^{1}$ Department of Poultry Science, Madras Veterinary College, Chennai, Tamil Nadu, India \\ ${ }^{2}$ Instructional Livestock Farm Complex, MMC, Chennai, Tamil Nadu, India \\ ${ }^{3}$ Central University Laboratory, Chennai, Tamil Nadu, India \\ ${ }^{4}$ DCAPS, Chennai, Tamil Nadu, India \\ *Corresponding author
}

\section{A B S T R A C T}

\begin{tabular}{|l|}
\hline Ke y w or d s \\
Allium sativum, \\
Andrographis paniculata, \\
$\begin{array}{l}\text { Haematological, } \\
\text { Biochemical, Broiler }\end{array}$ \\
\hline Article Info \\
\hline $\begin{array}{l}\text { Accepted: } \\
\text { 26 September } 2018 \\
\text { Available Online: } \\
\text { 10 October } 2018\end{array}$ \\
\hline
\end{tabular}

\section{Introduction}

Commercial broiler is one of the fastest growing birds; its growth and development are dynamic processes. Presently a need has arisen to completely avoid usage of antibiotics in poultry feeding due to increasing consumer concern for poultry drug residues in meat and egg. Hence, an alternative to antibiotics like probiotics, prebiotics, synbiotics and phytobiotics are being tried in poultry rations to improve growth, productivity and immunity against diseases. In this connection,

\begin{abstract}
The effect of supplementation of garlic and nilavembu on haematological and biochemical parameters of commercial broiler chicken was studied in 300 commercial broiler for a period of six weeks. There were 5 treatment groups and each treatment had three replicates with 20 chicks. The treatment groups containing garlic and nilavembu at different levels, such as $0 \mathrm{~g}$ garlic $+0 \mathrm{~g}$ nilavembu $\left(\mathrm{T}_{1^{-}}\right.$control $), 5 \mathrm{~g}$ garlic $+1 \mathrm{~g}$ nilavembu $\left(\mathrm{T}_{2}\right), 10 \mathrm{~g}$ garlic $+1 \mathrm{~g}$ nilavembu $\left(\mathrm{T}_{3}\right), 5 \mathrm{~g}$ garlic $+2 \mathrm{~g}$ nilavembu $\left(\mathrm{T}_{4}\right)$ and $10 \mathrm{~g}$ garlic $+2 \mathrm{~g}$ nilavembu $\left(\mathrm{T}_{5}\right) / \mathrm{kg}$ of basal diet, respectively. WBC $\left(\mathrm{x} 10^{3}\right)$ count revealed a highly significant $(\mathrm{P}<0.01)$ difference between treatment groups. Similarly, birds in $\mathrm{T}_{5}$ group had significantly highest lymphocyte count and lowest cholesterol and triglyceride levels $(\mathrm{P}<0.01)$. Hence, it may be concluded that supplementation of garlic and nilavembu had positive effect on lowering cholesterol, triglyceride and enhance the immunity.
\end{abstract}

phytobiotic such as, garlic (Allium sativum) and nilavembu (Andrographis paniculata) could be used as an alternative. It is expected to produce positive effects on production parameters and immune responses. Garlic is a spice proven as herbal medicine for the prevention and treatment of various diseases. It has anti-bacterial, anti-viral, anti-fungal, anti-protozoal, anti-cancer, anti-oxidant, immunomodulatory, anti-inflammatory, hypoglycemic and hypocholesteremic effect. Moreover, it improves body weight gain and digestibility. It decreases the bad cholesterol 
and also augments meat quality parameters (Rehman and Munir, 2015). Similarly, nilavembu reported to possess antiinflammatory, hepato-protective, astringent and anti-pyretic properties and helps in arresting dysentery, influenza and bronchitis (Salna et al., 2011).

The effect of garlic and nilavembu has been studied separately in a few researches. But the screening of garlic and nilavembu revealed the presence of some phytochemical compounds which are common to each other. Hence, the present experiment was conducted to study the combined effect of garlic and nilavembu on haematological and biochemical parameters of commercial broiler chicken.

\section{Materials and Methods}

The present study was performed in the Department of Poultry Science, Madras Veterinary College, TANUVAS (Chennai, India). Day old Cobb chicks (300) were randomly allotted to 3 replicate with 20 chicks each and these replicate were distributed randomly to 5dietary treatments as shown in Table 1.

\section{Experimental ration}

The standard recommended commercial diet was prepared as per BIS 2007 broiler standard with similar nutrient composition for all the treatments. Fresh garlic were purchased from local market and pure nilavembu powder was obtained from the Government Siddha Medical College, Chennai. All the experimental feeds were prepared at the Central Feed Technology Unit, Kattupakkam, Tamil Nadu Veterinary and Animal Sciences University, as presented in Table 2. The experimental birds were fed ad libitum throughout the experimental period. The birds were fed with broiler pre-starter (0-7 days), starter (8-21 days) and finisher (22-42 days).

\section{Parameters studied}

\section{Haematological and biochemical parameters}

On the $42^{\text {nd }}$ day of study, blood samples were randomly collected from one male and one female of each replicate, total of six birds per treatment. The blood samples were collected via the wing veins using sterile needles and syringes. The blood samples for haematological parameters were collected into well-labeled vacutainer containing ethylene diamine tetra acetic acid (EDTA), as anticoagulant. The samples were investigated for the following haematological parameters packed cell volume (PCV), red blood cell count (RBC), white blood cell (WBC), haemoglobin, Mean Corpuscular Volume (MCV), Mean Corpuscular Haemoglobin $(\mathrm{MCH})$, Mean Corpuscular Haemoglobin Concentration (MCHC) and Differential leucocyte Count (Bancroft and Marilyn, 2008). Serum samples were analyzed for total protein, serum cholesterol and triglyceride. The total protein level in the serum samples were estimated in A15 Biosystem auto analyser by using commercial available AGAPPE kit based on Direct Biuret method (Gornall et al., 1949) and BCG method (Doumas et al., 1970). Cholesterol and Triglyceride in the serum were estimated using A15 Biosystem auto analyser using commercially available Kits from AGAPPE Diagnostic Ltd based on CHOD- PAP methodology (Allain et al., 1974) and GPO PAP method (Buccolo and David, 1973) respectively.

\section{Statistical analysis}

All the statistical analysis were performed by using SPSS software (version 20.0) as per Snedecor and Cochran (1994). The mean were compared by one way ANOVA for significant difference among treatment. All the per cent 
values in the experiment were transformed to their arcsine roots before subjecting to statistical analysis.

\section{Results and Discussion}

\section{Haematological parameters}

The effect of supplementation of garlic and nilavembu on the haematological parameters (Mean \pm S.E) such as PCV (\%) $\mathrm{Hb}(\mathrm{g} / \mathrm{dl})$, $\operatorname{RBC}\left(\mathrm{x} \mathrm{10} 0^{6}\right)$ and WBC (x 10 $\left.{ }^{3}\right)$ in commercial broiler chicken were presented in Table 3 . The result on WBC $\left(\mathrm{x} \mathrm{10}{ }^{3}\right)$ count revealed a highly significant $(\mathrm{P}<0.01)$ difference between the treatment groups with highest count in $\left(\mathrm{T}_{5}\right) 10$ $\mathrm{g}$ of garlic and $2 \mathrm{~g}$ of nilavembu fed group (11.60 \pm 0.49$)$ when compared with control $(7.21 \pm 0.28)$ group. Whereas treatment groups $\mathrm{T}_{1}, \mathrm{~T}_{2}$ and $\mathrm{T}_{3}$ had comparable WBC count; however, it was not significant. It was also found that, there was a non- significant difference exist among the various treatment groups with respect to PCV (\%), $\mathrm{Hb}(\mathrm{g} / \mathrm{dl})$ and RBC (x 106) count. Mean $( \pm$ S.E) value of $\mathrm{MCV}, \mathrm{MCH}$ and $\mathrm{MCHC}$ of commercial broiler chicken as influenced by supplementation of garlic and nilavembu was presented in Table 4. It was observed that, there is a non-significant different exist among the different treatment groups with respect to $\mathrm{MCV}, \mathrm{MCH}$ and $\mathrm{MCHC}$, respectively.

The effect of supplementation of garlic and nilavembu on differential count mean $( \pm$ S.E $)$ of commercial broiler chicken was presented in Table 5. Statistical analysis of data on differential count showed that only lymphocyte had a significant $(\mathrm{P}<0.05)$ influence in the group fed with $\left(\mathrm{T}_{5}\right) 10 \mathrm{~g}$ of garlic and $2 \mathrm{~g}$ of nilavembu $(58.80 \pm 0.73)$ and it was comparable with $\mathrm{T}_{4}(57.83 \pm 1.19)$ and control (56.00 \pm 1.06) group. However, heterophil, eosinophil, basophil and monocyte count showed a non-significant difference among the various treatment groups.
The above results were in accordance with the earlier reports of Fadlalla et al., (2010) and Eid and Iraqi (2014) who also observed that total WBC count had a significant $(\mathrm{P}<0.05)$ differences among the dietary treated groups. On contrary to the above finding, Jimoh et al., (2012) and Elagib et al., (2013) who observed that supplementation of garlic and nilavembu had a non- significant difference on blood haematological parameters.

The mean Corpuscular Haemoglobin $(\mathrm{MCH})$, Mean Corpuscular Volume (MCV) and Mean Corpuscular Haemoglobin Concentration (MCHC) expressed a non- significant difference among various treatment groups. These finding were in agreement with Toghyani et al., (2011) who observed that mean corpuscular volume (MCV), mean corpuscular haemoglobin $(\mathrm{MCH})$ and mean corpuscular haemoglobin concentration (MCHC) were not significantly influenced by the supplementation of garlic.

\section{Serum bio-chemical parameters}

The effect of supplementation of garlic and nilavembu on serum biochemical parameters (Mean \pm S.E) such as total serum protein $(\mathrm{mg} / \mathrm{dl})$, total serum cholesterol $(\mathrm{mg} / \mathrm{dl})$ and triglyceride $(\mathrm{mg} / \mathrm{dl})$ of commercial broiler chicken at sixth week of age was presented in the Table 6. Statistical analysis of data on total serum cholesterol and triglyceride revealed a highly significant $(\mathrm{P}<0.01)$ difference upon the supplementation of garlic and nilavembu among the different treatment group, where as a non-significant difference was noticed among the various treatment groups with the respect to total serum protein. The lowest total serum cholesterol and triglyceride values were found in $10 \mathrm{~g}$ of garlic and $2 \mathrm{~g}$ of nilavembu $\left(\mathrm{T}_{5}\right)$ supplemented group $(132.81 \pm 0.86)$ and $(66.42 \pm 1.09)$ respectively, and it was significantly $(\mathrm{P}<0.01)$ lower than all the other groups. 
Table.3 Effect of supplementation of garlic and nilavembu on PCV (\%), Hb (g/dl), RBC (x 10 ${ }^{6}$ ) and WBC $\left(\begin{array}{ll}x & 10^{3}\end{array}\right)($ Mean \pm S.E) of commercial broiler chicken at 6 weeks of age

\begin{tabular}{|c|c|c|c|c|}
\hline Treatments & PCV $(\%)$ & Hb (g/dl) & $\operatorname{RBC}\left(\times 10^{6}\right)$ & $\mathrm{WBC}\left(\mathrm{x} 10^{3}\right)$ \\
\hline $\begin{array}{c}\mathbf{T}_{1} \\
(\text { control) }\end{array}$ & $39.18 \pm 0.49$ & $10.39 \pm 0.37$ & $2.31 \pm 0.27$ & $7.21^{c} \pm 0.28$ \\
\hline $\begin{array}{c}\mathbf{T}_{2} \\
(\mathbf{G}-\mathbf{5} \mathbf{g}+\mathbf{N}-1 \mathbf{g})\end{array}$ & $40.06 \pm 0.26$ & $10.77 \pm 0.27$ & $2.62 \pm 0.10$ & $8.23^{c} \pm 0.45$ \\
\hline $\begin{array}{c}\mathrm{T}_{\mathbf{3}} \\
(\mathrm{G}-\mathbf{1 0} \mathrm{g}+\mathrm{N}-\mathbf{1} \mathrm{g})\end{array}$ & $39.12 \pm 0.35$ & $10.54 \pm 0.09$ & $2.57 \pm 0.19$ & $8.23^{c} \pm 0.30$ \\
\hline $\begin{array}{c}\mathrm{T}_{4} \\
(\mathrm{G}-\mathbf{5} \mathrm{g}+\mathrm{N}-\mathbf{2} \mathrm{g})\end{array}$ & $39.85 \pm 0.29$ & $10.77 \pm 0.27$ & $2.68 \pm 0.17$ & $10.53^{b} \pm 0.25$ \\
\hline $\begin{array}{c}\mathrm{T}_{5} \\
(\mathrm{G}-10 \mathrm{~g}+\mathrm{N}-2 \mathrm{~g})\end{array}$ & $39.18 \pm 0.35$ & $10.48 \pm 0.26$ & $2.54 \pm 0.19$ & $11.60^{\mathrm{a}} \pm 0.49$ \\
\hline F value & 1.050 & 0.417 & 0.534 & 21.456 \\
\hline Significant & NS & NS & NS & $* *$ \\
\hline
\end{tabular}

Means bearing different superscripts within the same column differ significantly

NS - No Significant ** - Highly significant $(\mathrm{P}<0.01)$ G- Garlic N- Nilavembu

Table.4 Effect of supplementation of garlic and nilavembu on MCV (fl), $\mathrm{MCH}$ (pg) and MCHC (pg) (Mean \pm S.E) of commercial broiler chicken at 6 weeks of age

\begin{tabular}{|c|c|c|c|}
\hline Treatments & MCV (fl) & MCH (pg) & MCHC (pg) \\
\hline $\begin{array}{c}\mathrm{T}_{1} \\
\text { control) }\end{array}$ & $143.06 \pm 0.94$ & $41.92 \pm 0.36$ & $26.53 \pm 0.87$ \\
\hline $\begin{array}{c}\mathrm{T}_{2} \\
(\mathrm{G}-5 \mathrm{~g}+\mathrm{N}-1 \mathrm{~g})\end{array}$ & $142.94 \pm 1.83$ & $41.12 \pm 1.10$ & $26.89 \pm 0.77$ \\
\hline $\begin{array}{c}\mathrm{T}_{3} \\
(\mathrm{G}-10 \mathrm{~g}+\mathrm{N}-1 \mathrm{~g})\end{array}$ & $142.23 \pm 1.07$ & $41.16 \pm 1.42$ & $26.96 \pm 0.22$ \\
\hline $\begin{array}{c}\mathrm{T}_{4} \\
(\mathrm{G}-5 \mathrm{~g}+\mathrm{N}-2 \mathrm{~g})\end{array}$ & $140.92 \pm 1.47$ & $41.28 \pm 1.41$ & $26.04 \pm 0.14$ \\
\hline $\begin{array}{c}\mathrm{T}_{5} \\
(\mathrm{G}-10 \mathrm{~g}+\mathrm{N}-2 \mathrm{~g})\end{array}$ & $143.07 \pm 1.02$ & $41.34 \pm 1.20$ & $26.77 \pm 0.52$ \\
\hline F value & 0.489 & 0.022 & 0.406 \\
\hline Significant & $\mathrm{NS}$ & $\mathrm{NS}$ & $\mathrm{NS}$ \\
\hline
\end{tabular}

NS - No Significant G- Garlic N- Nilavembu FL- Femto litre; pg- Pico gram 
Table.5 Effect of supplementation of garlic and nilavembu on differential count (Mean \pm S.E) of commercial broiler chicken at 6 weeks of age

\begin{tabular}{|c|c|c|c|c|c|}
\hline Treatments & Heterophils & Eosinophils & Basophils & Lymphocytes & Monocytes \\
\hline $\begin{array}{c}\mathrm{T}_{1} \\
(\text { control })\end{array}$ & $26.16 \pm 0.47$ & $2.83 \pm 0.30$ & $1.16 \pm 0.17$ & $56.00^{\mathrm{ab}} \pm 1.06$ & $4.33 \pm 0.33$ \\
\hline $\begin{array}{c}\mathrm{T}_{2} \\
(\mathrm{G}-5 \mathrm{~g}+\mathrm{N}-1 \mathrm{~g})\end{array}$ & $26.00 \pm 0.44$ & $2.83 \pm 0.40$ & $1.33 \pm 0.21$ & $55.00^{\mathrm{b}} \pm 1.09$ & $4.16 \pm 0.40$ \\
\hline $\begin{array}{c}\mathrm{T}_{3} \\
(\mathrm{G}-10 \mathrm{~g}+\mathrm{N}-1 \mathrm{~g})\end{array}$ & $26.83 \pm 0.40$ & $2.50 \pm 0.34$ & $1.00 \pm 0.25$ & $55.00^{\mathrm{b}} \pm 1.29$ & $4.16 \pm 0.30$ \\
\hline $\begin{array}{c}\mathrm{T}_{4} \\
(\mathrm{G}-5 \mathrm{~g}+\mathrm{N}-2 \mathrm{~g})\end{array}$ & $26.66 \pm 0.80$ & $2.66 \pm 0.21$ & $1.16 \pm 0.16$ & $57.83^{\mathrm{ab}} \pm 1.19$ & $4.17 \pm 0.31$ \\
\hline $\begin{array}{c}\mathrm{T}_{5} \\
(\mathrm{G}-10 \mathrm{~g}+\mathrm{N}-2 \mathrm{~g})\end{array}$ & $25.60 \pm 0.74$ & $2.40 \pm 0.24$ & $1.40 \pm 0.24$ & $58.80^{\mathrm{a}} \pm 0.73$ & $4.20 \pm 0.37$ \\
\hline F value & 0.696 & 0.373 & 0.541 & 2.265 & 0.045 \\
\hline Significant & $\mathrm{NS}$ & $\mathrm{NS}$ & $\mathrm{NS}$ & $*$ & $\mathrm{NS}$ \\
\hline
\end{tabular}

Means bearing different superscripts within the same column differ significantly

* - Significant $(\mathrm{P}<0.05)$ NS- No Significant G- Garlic N- Nilavembu

Table.6 Effect of supplementation of garlic and nilavembu on total serum protein $(\mathrm{mg} / \mathrm{dl})$, total serum cholesterol $(\mathrm{mg} / \mathrm{dl})$ and triglyceride $(\mathrm{mg} / \mathrm{dl})($ Mean $\pm \mathrm{S} . \mathrm{E})$ of commercial broiler chicken at 6 weeks of age

\begin{tabular}{|c|c|c|c|}
\hline Treatments & $\begin{array}{l}\text { Total serum protein } \\
(\mathrm{mg} / \mathrm{dl})\end{array}$ & $\begin{array}{l}\text { Total serum cholesterol } \\
(\mathrm{mg} / \mathrm{dl})\end{array}$ & $\begin{array}{l}\text { Triglyceride } \\
(\mathrm{mg} / \mathrm{dl})\end{array}$ \\
\hline $\begin{array}{c}\mathrm{T}_{1} \\
(\text { control })\end{array}$ & $3.45 \pm 0.02$ & $154.19^{\mathrm{a}} \pm 1.27$ & $105.17^{\mathrm{a}} \pm 1.48$ \\
\hline $\begin{array}{c}\mathrm{T}_{2} \\
(\mathrm{G}-5 \mathrm{~g}+\mathrm{N}-1 \mathrm{~g})\end{array}$ & $3.55 \pm 0.12$ & $152.43^{\mathrm{a}} \pm 0.58$ & $95.14^{\mathrm{b}} \pm 1.14$ \\
\hline $\begin{array}{c}\mathrm{T}_{3} \\
(\mathrm{G}-10 \mathrm{~g}+\mathrm{N}-1 \mathrm{~g})\end{array}$ & $3.50 \pm 0.12$ & $144.49^{\mathrm{b}} \pm 1.26$ & $83.61^{\mathrm{c}} \pm 1.04$ \\
\hline $\begin{array}{c}\mathrm{T}_{4} \\
(\mathrm{G}-5 \mathrm{~g}+\mathrm{N}-2 \mathrm{~g})\end{array}$ & $3.55 \pm 0.04$ & $142.00^{\mathrm{b}} \pm 0.66$ & $75.18^{\mathrm{d}} \pm 1.66$ \\
\hline $\begin{array}{c}\mathrm{T}_{5} \\
(\mathrm{G}-10 \mathrm{~g}+\mathrm{N}-2 \mathrm{~g})\end{array}$ & $3.55 \pm 0.08$ & $132.81^{\mathrm{c}} \pm 0.86$ & $66.42^{\mathrm{e}} \pm 1.09$ \\
\hline F value & 0.275 & 78.630 & 138.840 \\
\hline Significant & $\mathrm{NS}$ & $* *$ & $* *$ \\
\hline
\end{tabular}

Means bearing different superscripts within the same column differ significantly

** - Highly significant $(\mathrm{P}<0.01)$ NS- No Significant G- Garlic N-Nilavembu

From this experiment, it was found that with increase in garlic and nilavembu levels in the feed, there was decrease in cholesterol and triglyceride level in serum. However, the highest level of total cholesterol was obtained from control group.
Despite the fact that the nutrient levels of garlic and nilavembu, they had strong impact on the growth and serum lipid levels of broilers. The supplementation of garlic and nilavembu significantly improved the growth of the chicks. However, the mixtures of garlic 
and nilavembu had reduced serum lipids and abdominal fat pad without any adverse effect on the growth of the broiler chickens. This reveals that addition of the mixture of garlic and nilavembu in broiler diet could be more beneficial in lowering lipids in broiler chickens than sole addition of garlic and nilavembu. Furthermore, the results of hypolipidemic action of the supplements showed that they could be used to lower some of the risk factors associated with the development of cardiovascular diseases and cancer whether in animals or human beings. It has been reported that lowering blood levels of cholesterol and fats may help to prevent heart disease, angina, stokes and heart attacks (Anonymous, 2008).

Various research's reported that (Jimoh et al., (2012) and Puvaca et al., (2014) the supplementation of garlic significantly $(\mathrm{P}<0.05)$ decreased the level of total cholesterol, triglyceride which was in agreement with the finding of the present study. This might be due to garlic contains high levels of bioactive saponin which form insoluble complexes with cholesterol and inhibit intestinal absorption of endogenous and exogenous cholesterol. These key saponins in garlic also possess the ability to inhibit key enzymes in the cholesterol and lipid biosynthetic pathways. Allicin also inhibit the action of hydroxymethyl gutaryl CoA reductase, which is the most important enzyme that participates in the synthesis of cholesterol and lipids. On contrary Anvar et al., (2012) who observed that there was a non- significant difference in total cholesterol and triglyceride among the garlic treated groups. Combination of garlic and nilavembu also gave lower total serum cholesterol and triglyceride level in commercial broilers.

It was concluded that the supplementation of garlic and nilavembu showed a hypolipidemic effects on the serum cholesterol and triglyceride levels without affecting the growth performance of the broilers and also enhance the immunity through increased leucocyte count. The combined effect of garlic and nilavembu showed a positive response in the broiler production.

\section{References}

Allain, C.C., Poon, L.S., Chan, C.S.G., Richmond, W and Fu, P.C. 1974. Enzymatic determination of total serum cholesterol. Linc. Chem. (20): 470- 475.

Anonymous, (2008). Cholestyramine resin. http://www.savemedication.com accessed on 06/02/08.

Anvar, A.B Dastar, Nejad, J.G, Sung, K, Lohakare, J and Forghani, F. 2012. Effects of garlic and thyme extracts on growth Performance and Carcass Characteristics of broiler chicks. $J$. Anim. Sci. Technol. 54(3): 185-190.

Bancroft, J.D and Marilyn, G. 2008. Theory and practice of histological techniques. Sixth edition.

Buccolo, G and David, H. 1973. Quantitative determination of triglyceride by the use of enzyme. Clin. Chem. (19): 476-482.

Bureau of Indian Standard, 2007. Indian Standard. Poultry Feeds-Specification (Fifth revision) IS 1374: 2007, pp: 1-30.

Doumas, B.T., Watson, W.A and Biggs, H.G. 1970. Albumen standards and measurement of serum albumen with bromcresol. Clin. Chem. Acta, 258: 2130.

Eid, K.M and Iraqi, M.M. 2014. Effect of garlic powder on growth performance and immune response for Newcastle and Avian influenza virus disease in broiler chickens. $2^{\text {nd }}$ International Conference on Biotechnology Application in Agriculture, Benha University, Moshtohor and Hurghada. 8-12. 
Elagib, H.A.A., El-Amin, Elamin, W.I.A and Malik, H.E.E. 2013. Effect of dietary garlic (Allium sativum) supplementation as feed additive on broiler performance and blood profile. J. Anim. Sci. Adv. 3(2): 58-64.

Fadlalla, I.M.T., Mohammad, B.H and Bakhiet, A.O. 2010. Effect of feeding garlic on the performance and Immunity of broilers. Asian Journal of Poultry Science, 4 (4): 182-189.

Gornall, A.G., Bardawill, C.J and David, M.M. 1949. Determination of serum protein by means of the biuret reaction. J. Biol. Chem. (177): 751-766.

Jimoh. A.A., Olorede, B.R., Abubakar, A., Fabiyi, J.P., Ibitoye, E.B., Suleiman, N and Garba, S. 2012. Lipids profile and haematological indices of broiler chickens fed garlic (Allium sativum) supplemented diets. J. Vet. Adv. 2(10): 474-480.

Puvaca, N., Kostadinovic, L.J., Ljubojevic, D.L., Popovic, S.D., Dokmanovc, B and Stanacev, S.V. 2014. Effect of dietary garlic addition on productive performance and blood lipid profile of Broiler Chickens. Institute for Animal Husbandry, Belgrade-Zwmun, 30(4): 669-676.

Rehman and Munir, M.T. 2015. Effect of garlic on the health and performance of broilers. Open Access Journal Veterinaria, 3(1): 32-39.

Salna, K.P., Sreejith, K., Uthiralingam, M., Mithu, A.P., John, M.C and Albin. T.F. (2011). A comparative study of phytochemicals investigation of Andrographis paniculata and Murrayakoenigii. J Pharm PharmSci, 3(3).

Snedecor, G.W and Cochran, G W. 1994. Statistical methods. The Iowa state Univ. Press, Ames Iowa U.S.A. 507.

Toghyani, M., Majid, T., Abbasali, G., Gholamreza, G and Shahin, E.S. 2011. Evaluation of cinnamon and garlic as antibiotic growth promoter substitutions on performance, immune responses, serum biochemical and haematological parameters in broiler chicks. Livestock Science, 138: 167-173.

\section{How to cite this article:}

Toriyali Arify, S. Ezhil Valavan, K. Manimaran, A. Sundaresan and Varun, A. 2018. Effect of Supplementation of Garlic (Allium sativum) and Nilavembu (Andrographis paniculata) on Hematological and Serum Biochemical Parameters of Commercial Broiler Chicken. Int.J.Curr.Microbiol.App.Sci. 7(10): 3649-3656. doi: https://doi.org/10.20546/ijcmas.2018.710.422 